\title{
SIMPLIFIED DISSECTION AS AN AID IN CARCASS EVALUATION ON THE LANDRACE AND YORKSHIRE BREEDS
}

\author{
Unto UUsisalmi \\ Department of Animal Breeding, University of Helsinki
}

Received April 23, 1971

\begin{abstract}
Information on carcass quality obtained from dissection and conventional carcass evaluation was studied on the Landrace and Yorkshire breeds. Progeny testing pigs ( $\mathrm{n}=$ 196) were slaughtered at a weight of c. $90 \mathrm{~kg}$. After conventional carcass evaluation, the carcass half was dissected. The objects of study were the most valuable parts of the half carcass ( = ham + carré + back + fore back + shoulder + kidney fat) and its skin + fat and meat + bone components. The possibility of restricting the dissection to the ham and the back was also examined. By means of the least squares methods the following results were obtained: The effect of the slaughter weight on the skin + fat, the meat + bone and the valuable part was very significant. The variation due to age was not significant. The carcass quality on the gilts was better than that of the castrates. By stepwise multiple regression procedures estimations were derived for the skin + fat component, the meat + bone component and the most valuable part of the carcass. By dissection of the ham and the back more information was generally obtained about the slaughter quality of the most valuable part than was obtained by the conventional carcass evaluation. The index $\left(=\frac{\mathrm{A}}{\mathrm{B}} \times \frac{\mathrm{A}}{\mathrm{C}} \times 10\right)$ was calculated, in which $\mathrm{A}=$ weight of the meat + bone component, $\mathrm{B}=$ age in days and $\mathbf{C}=$ weight of the half carcass. The index correlated with the skin + fat component and its percentage as follows: $\mathrm{r}=-0.34 * *--0.55^{* * *}$, and with the meat + bone component and its percentage: $r=0.77 * * *-0.78 * * *$. Possibilities of developing the index were examined.
\end{abstract}

While the production of pigment has increased, the demand has increasingly centred on fat-free and low-caloried red meat. For years, the price paid to the producer has consequently been determined by the carcass weight and the thickness of the back fat. In the retail trade and the meat industry, however, the value of the carcass is affected not only by its fattiness but also by the relative proportions of various parts of the carcass and by the quality of the meat. Typical of the development is the increase in the value of back, hams, shoulders and even side, and the decrease in the value of head, trotters, shank and belly.

Pig breeders have tired to adjust their methods of carcass evaluation to this situation by a) analysis of the anatomic composition of the carcass by dissection (BLENDL $1966 \mathrm{a}$, Blendl 1966 b, Weniger et al. 1967, Pedersen 1968, Lohse et al. 1969, Cllausen et al. 1970), b) connecting carcass quality more closely to its economic value (BöcKENHOFF et al. 1967, SYсн \& Horst 1969, SCHÖN 1970), and c) replacing the subjective points evaluation, e.g. of the ham, with objective measurements (BLEND 1966 b, PARTANen 1969). 
Complete dissection of the carcass of test pigs is a laborious and expensive process. An alternative approach is a simplified dissection where the carcass is divided into retail parts some of which are further dissected to assess the leanness.

The objectives set for the present study were approached as follows. 1) An examination was made of the possibilities of restricting dissection analysis to individual parts of the carcass. 1) An analysis was made of the effects of carcass weight, age and sex on the most valuable part of the carcass and its components. 3) An investigation was made of the suitability of identical dissection models for the Landrace breed and the Yorkshire breed. 4) Information obtained by conventional evaluation of the carcass was compared with information obtained by partial dissection. 5) An examination was made of the position of the "new index" as a measurement of the fattiness and the leanness of the carcass, although the presentation of a final test index will not be necessary until the completion of a test period lasting several years, when, for instance, the heritability of individual parts of the carcass has been determined with relative certainty.

\section{Material}

Landrace $(\mathrm{n}=119)$ and Yorkshire $(\mathrm{n}=77)$ progeny testing pigs were reared at the Pohjanmaa litter testing station to a live weight of c. $90 \mathrm{~kg}$. The feeding was the standard mixture for progeny testing pigs (PARTANEN 1969). Conventional carcass evaluation was done one day after slaughter, when the left half of the carcass was dissected. The chief objects of examination were "the most valuable part» of the half carcass (ham + carré + back + fore back + shoulder + kidney fat: Uusisalmi 1969 a), the skin +fat and the meat+bone components, and the percentages of these in the half carcass. The dissection results were used to calculate for each pig the daily gain of the meat + bone component of the most valuable part $\frac{(\mathrm{A})}{\bar{B}}$ and the new index $\left(=\frac{\mathrm{A}}{\mathrm{B}} \times \frac{\mathrm{A}}{\mathrm{C}} \times 10\right)$ in which $\mathrm{A}=$ the weight of the meat + bone component of the most valuable part of the half carcass, $\mathrm{B}=$ age in days, and $\mathrm{C}=$ the weight of the half carcass.

\section{Methods}

The least squares procedures (Harvey 1966, SCG 1968) were used to analyse overall variances of the most valuable part of the carcass and its components in order to ascertain the role of the following factors in the variation: linear regression on slaughter age and slaughter weight, sex, breed, their interaction and the years 1967 1969 within breeds.

The following model was used to analyse the variances: $y_{i j k 1}=\alpha+a_{i}+b_{j}+$ $c_{j k}+(a b)_{i j}+$ d. $x_{i j k 1}+g \cdot z_{i j k 1}+e_{i j k 1}$; in which $a_{i}=i$ th effect of sex, $b_{j}=j$ th effect of breed, $c_{j \mathbf{k}}=$ effect of $k^{\text {th }}$ year within the $j^{\text {th }}$ breed, $(a b)_{i j}=$ interaction of the $\mathrm{i}^{\text {th }}$ sex and the $\mathrm{j}^{\mathrm{th}}$ breed, $\mathrm{x}_{\mathrm{ijk1}}$ and $\mathrm{z}_{\mathrm{ijk} \mathbf{1}}=$ independent continuous variables, $\mathrm{d}$ and $\mathrm{g}=$ partial regression coefficients, and $\mathrm{e}_{\mathrm{ijk} \mathbf{1}}=$ random error.

Stepwise multiple regression analysis (SGC 1968). The results were processed by stepwise multiple regression analysis as follows: a) preliminary analyses $(\mathrm{n}=174)$ and $\mathrm{b}$ ) analyses by breed after supplementation ( $\mathrm{n}=119$ Landrace and 77 Yorkshire pigs) of the material.

The results provided the correlation matrix, the multiple correlation coefficients $(R)$, the coefficient of the multiple determination $\left(\mathrm{R}^{2}\right)$ and the partial regression coefficients, etc. The partial regression coefficients are not shown, for any of the explanatory variables are linearly dependent on one another. 


\section{Results and discussion}

Preliminary procedure (174 pigs). The possibilities of measuring the most valuable part of the carcass and its skin + fat and meat +bone components were analysed by stepwise multiple regression analysis. It should be pointed out thant the most valuable part of the carcass excludes the head, feet, shanks, neck, belly and sides. The sides may indeed be regarded as being included in the most valuable part of the carcass, but its dissection into its skin +fat and meat+bone components is time-consuming and rather laborious, and the side was consequently excluded for reasons of expediency. Reduction of the proportion of the listed relatively less valuable parts of the carcass is one of the aims of breeding, and it is hoped that this will be attained by selection for the biggest possible valuable part of the carcass and for its meat + bone component.

Table 1. Skin + fat component of the most valuable part of the carcass is estimated by means of stepwise multiple regression analysis. Optional explanatory variables $=34$ characteristics of conventional carcass evaluation and of dissection analysis. $\mathrm{n}=174$.

\begin{tabular}{|c|c|c|c|c|}
\hline \multirow[b]{2}{*}{ Step } & \multirow[b]{2}{*}{ Characteristics } & \multirow[b]{2}{*}{$\mathbf{r}$} & \multicolumn{2}{|c|}{ Cumulative } \\
\hline & & & $\mathbf{R}$ & $\mathbf{R}^{2} \%$ \\
\hline 1 & Skin + fat of back, $g$ & 0.80 & 0.80 & 64 \\
\hline 2 & n of ham, $g$ & 0.73 & 0.87 & 76 \\
\hline 3 & $" \quad$ of shoulder, $\mathrm{g}$ & 0.55 & 0.92 & 85 \\
\hline 4 & $" \quad$ of carre, $\mathrm{g}$ & 0.50 & 0.94 & 88 \\
\hline 5 & Kidney fat, $\mathrm{g}$ & 0.42 & 0.96 & 92 \\
\hline 6 & Skin + fat of fore back, $g$ & 0.34 & 0.98 & 96 \\
\hline 7 & Age, days & 0.01 & 0.98 & 96 \\
\hline 8 & Points: distribution of back fat & -0.64 & 0.98 & 96 \\
\hline $\begin{array}{l}r>0 \\
r>0\end{array}$ & $\begin{array}{lll}0.15 & \text { signif. at } 5 \% & \text { level } \\
0.20 " & 1 \% & \end{array}$ & & & \\
\hline $\mathbf{r}>\mathbf{c}$ & $0.25 \Rightarrow " \quad 0.1 \% \quad "$ & & & \\
\hline
\end{tabular}

Table 1 shows an estimation for the measurement of the variance of the skin + fat component of the most valuable part of the carcass. The skin + fat model in the six first steps of the regression analysis included the following characteristics in the order listed: the skin +fat of the back, ham, shoulder and carré, the kidney fat and the skin +fat of the fore back. The $\mathrm{R}^{2}=0.96$. The Table moreover gives the phenotypical correlation (r) of every individual characteristic to the skin + fat component of the most valuable part. To exemplify, the distribution points for the back fat $(\mathrm{r}=-0.64 * * *)$, the thickness of the back fat $\left(\mathrm{r}=0.67^{* * *}\right)$ and the thickness of the side fat $(\mathrm{r}=0.67 * * *)$ correlate very significantly with the skin + fat component of the most valuable part of the carcass, but are, with the exception of the first-mentined, excluded from the model.

The estimation of the meat + bone component of the most valuable part of the carcass (Table 2) first included the following characteristics, in the order given: the meat + bone parts of the ham, back, shoulder, fore back and carré. After this, the $\mathrm{R}^{2}$ percentage was 98. The meat+bone component of the most valuable part of the carcass was obtained as the sum of the stated parts. It may be pointed out that the back fat and the side fat correlate very significantly with the meat + bone component of the most valuable part of the carcass $\left(\mathrm{r}=-0.36^{* * *}\right.$ and $\left.\mathrm{r}=0.32 * * *\right)$.

The results are fairly consistent with the results obtained at Puistola Pig Husbandry Experiment Station (Uusisalmi $1969 \mathrm{a}$ and b). 
Table 2. Meat + bone component of the most valuable part of the carcass is estimated by means of stepwise multiple regression analysis. Optional explanatory variables $=34$ characteristics of conventional carcass evaluation and of dissection analysis. $\mathrm{n}=174$.

\begin{tabular}{|c|c|c|c|c|}
\hline \multirow[b]{2}{*}{ Step } & \multirow[b]{2}{*}{ Characteristics } & \multirow[b]{2}{*}{$\mathbf{r}$} & \multicolumn{2}{|c|}{ Cumulative } \\
\hline & & & $\mathrm{R}$ & $\mathrm{R}^{2} \%$ \\
\hline 1 & Meat + bone of ham, $\mathrm{g}$ & 0.82 & 0.82 & 67 \\
\hline 2 & " of back, $\mathrm{g}$ & 0.67 & 0.90 & 81 \\
\hline 3 & $m \quad$ of shoulder, $\mathrm{g}$ & 0.55 & 0.95 & 90 \\
\hline 4 & $" \quad$ of fore back, $\mathrm{g}$ & 0.57 & 0.98 & 96 \\
\hline 5 & " of carrè, $\mathrm{g}$ & 0.54 & 0.99 & 98 \\
\hline 6 & Back, $\%$ of carcass & 0.16 & 1.00 & 100 \\
\hline 7 & Thickness of back fat, mm & -0.36 & 1.00 & 100 \\
\hline 8 & Shoulder, $\%$ of carcass & 0.05 & 1.00 & 100 \\
\hline 9 & Daily gain, $\mathrm{g}$ & 0.20 & 1.00 & 100 \\
\hline $\begin{array}{l}r>c \\
r>c \\
r>c\end{array}$ & 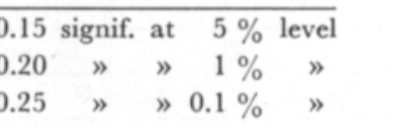 & & & \\
\hline
\end{tabular}

Table 3. Effects of age, live weight, sex, breed and years upon the most valuable part of the carcass and its components. The statistical significances were obtained by variance analysis. The percentages of variation were calculated from sums of squares. $\mathrm{n}=196$.

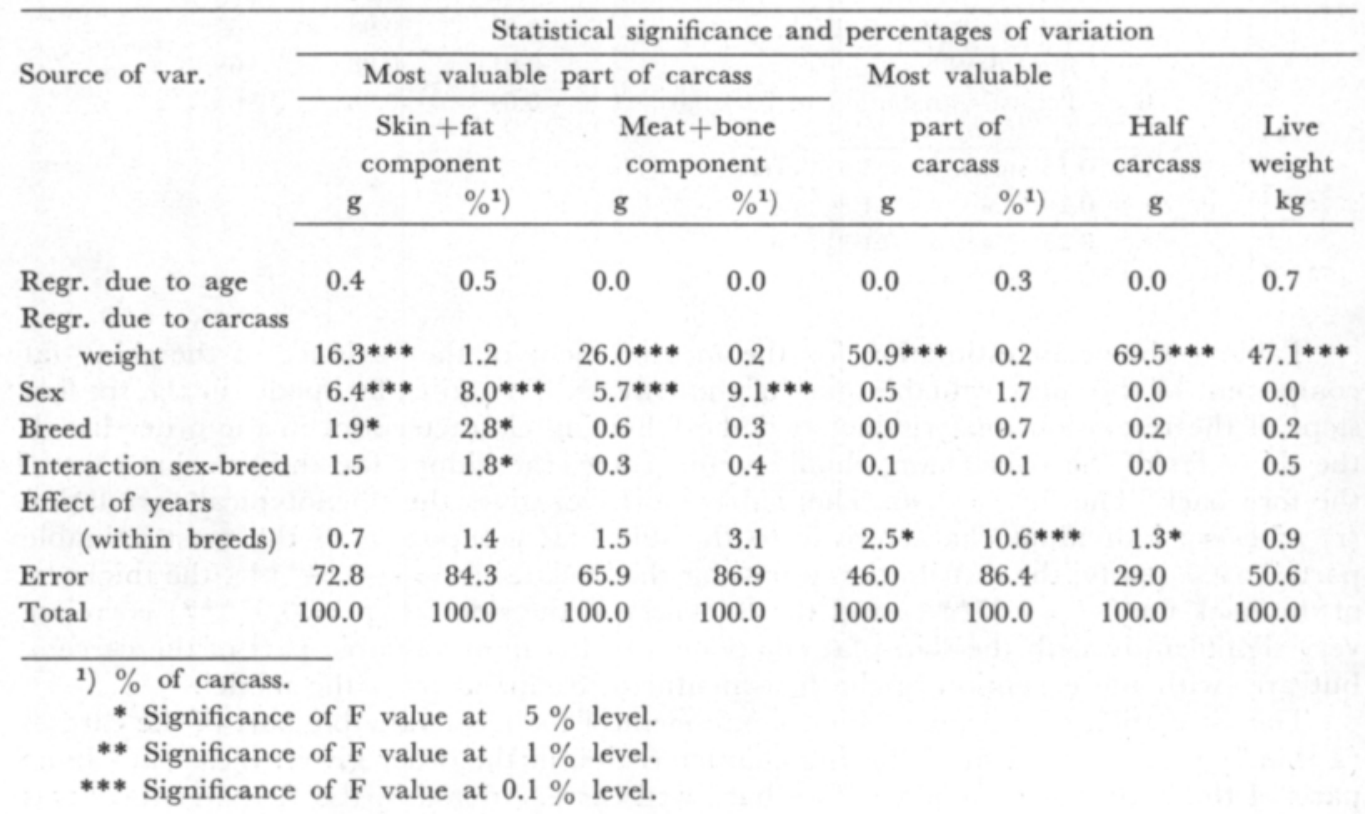

Effects of age, carcass weight, breed, sex and years. Table 3 shows the variation ratios and the statistical significances of the effects of certain factors influencing the variances in the most valuable part of the carcass and its components and their percentages.

The variation due to differences in slaughter weight in the most valuable part of the carcass and its skin + fat and meat + bone components was found to be statistically very significant. The effect of 
differences in slaughter weight was almost completely eliminated when the proportions of the most valuable part of the carcass and of its skin + fat and meat + bone components in the carcass were calculated. The same result can probably be arrived at by carrying out a correction bases on a linear regression on carcass weight. There was no need for correction by age in addition to correction of slaughter weight.

The effect of sex on the skin + fat and meat + bone components of the most valuable part of the carcass and on the percentages of these was statistically very significant. The females were found to be less fatty and more meaty than the castrates.

The effect of the years on the most valuable part of the carcass was almost significant, and on the relative proportion of the most valuable part it was very significant. The relative proportion of the most valuable part declined from year to year (1967-1969). The reason for this phenomenon is explicable in terms of the following factors: a) the decline in the fattiness of the carcass when selection was made for thin back fat, b) changes occurring in the manner of dissection, and c) the conditions in the piggery.

Table 4. Skin + fat component of the most valuable part of the carcass is estimated by means of stepwise multiple regression analysis in Landrace and Yorkshire pigs. Optional explanatory variables are results of conventional carcass evaluation and of dissection analysis, a total 35 characteristics.

\begin{tabular}{|c|c|c|c|c|c|c|}
\hline \multicolumn{4}{|c|}{ Estimation of skin + fat component } & \multicolumn{3}{|c|}{ Eestimation of percentage of skin + fat component } \\
\hline Step & Characteristics & $\mathbf{r}$ & $\mathrm{R}^{2} \%$ & Characteristics & $\mathbf{r}$ & $\mathbf{R}^{2} \%$ \\
\hline
\end{tabular}

Landrace $(n=119)$

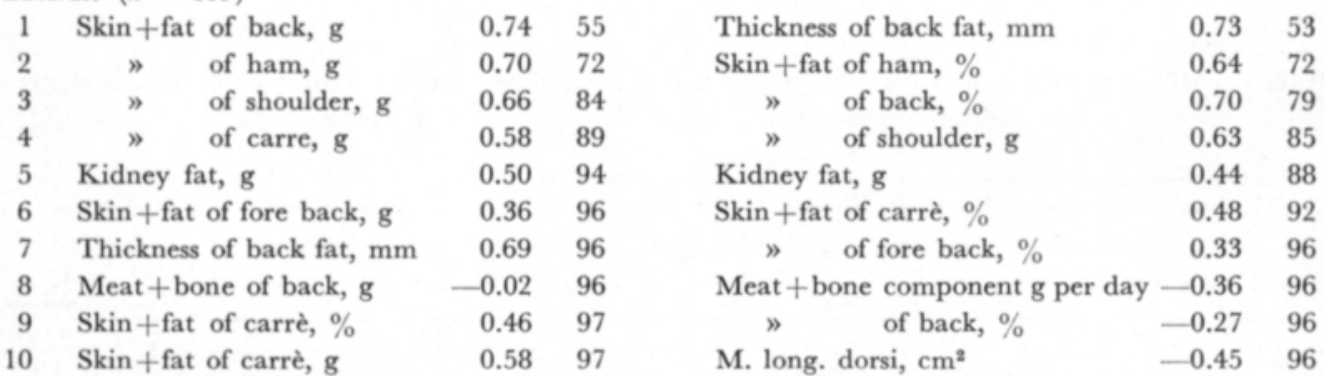

(dropped from model)

r $>0.19$ signif. at $5 \%$ level; r $>0.24$ signif. at $1 \%$ level; r $>0.31$ signif. at 0.1 level.

$\begin{array}{cccc}\text { rorkshire }(n=77) & & \\ 1 & \text { Skin +fat of back, g } & 0.81 & 65 \\ 2 & \text { " of ham, g } & 0.72 & 78 \\ 3 & \text { " of carrè, g } & 0.66 & 86 \\ 4 & \text { " of shoulder, g } & 0.59 & 90 \\ 5 & \text { Kidney fat, g } & 0.36 & 95 \\ 6 & \text { Skin +fat of fore back, g } & 0.37 & 99 \\ 7 & \text { M. long. dorsi, cm }{ }^{2} & -0.30 & 99 \\ 8 & \text { Meat +bone of back, g } & -0.07 & 99\end{array}$

$\begin{array}{crr}\text { Skin +fat of back, \% } & 0.80 & 64 \\ \text { " of ham, \% } & 0.68 & 76 \\ \text { " of carrè, \% } & 0.63 & 85 \\ \text { " of shoulder, \% } & 0.51 & 88 \\ \text { Kidney fat, g } & 0.35 & 92 \\ \text { Skin +fat of fore back, g } & 0.28 & 98 \\ \text { M. long. dorsi, cm }{ }^{2} & -0.42 & 98 \\ \text { Carcass weight, kg } & -0.02 & 98\end{array}$

r $>0.22$ signif. at $5 \%$ level; r $>0.29$ signif. at $1 \%$ level; r $>0.37$ signif. at $0.1 \%$ level.

Analyses by breed. Skintfat of the most valuable part. An estimation for the measurement of the skin + fat component of the most valuable part of the carcass and its percentage is shown for the $\mathrm{L}$ a $\mathrm{nd} \mathrm{r}$ a c e by stepwise multiple regression analysis in Table 4 . In the order listed, the six first steps of the model for the skin + fat of the most valuable part included: the skin + fat of the back, ham, shoulder 
and carré; the kidney fat, and the skin + fat of the fore back. The model measuring the percentage of the skin + fat component of the most valuable part included first the thickness of the back fat $\left(\mathrm{r}=0.73^{* * *}\right)$ and then the percentages of the skin + fat of the ham and of the back; the skin +fat of the shoulder; the kidney fat; and the percentages of the skin + fat in the carré and in the fore back. Table 4 shows the results of the same analysis for the Yorkshire breed, too. With the first six steps the estimations measuring the skin + fat component of the most valuable part and its percentage included the weight units of the following parts of their percentages, in the order listed: the skin + fat of the back, ham, carré and shoulder, the kidney fat; and the skin + fat of the fore back. The $\mathrm{R}^{2}$ percentage in the models amounted to $96-99$.

The correspondence of the estimations of the skin + fat component and its percentage can be regarded as good for the Landrace and especially so for the Yorkshire breed. This facilitates the carrying out of the measurement in practice when attempting to select for a small skin + fat component and its percentage. The models show differences between the breeds, but the undisputed position of the skin +fat components of the back and the ham emerge in both breeds.

Attention should always be given to the phenotypical correlation of each individual characteristic when results are being examined. The thickness of the back fat and the side fat remains important when estimations are being made of the skin + fat component and its percentage. On the other hand, the $\mathrm{m}$. long. dorsi also correlates significantly $(\mathrm{r}=-0.30 * *--0.45 * * *)$ with the skin + fat component of the most valuable part and its percentage in both the breeds.

Table 5. Meat + bone component of the most valuable part of the carcass is estimated by means of stepwise multiple regression analysis in Landrace and Yorkshire pigs.

Estimation of meat + bone component

Estimation of percentage of meat + bone component

\begin{tabular}{|c|c|c|c|c|c|c|}
\hline Step & Characteristics & $\mathbf{r}$ & $\mathbf{R}^{2} \%$ & Characteristics & $\mathbf{r}$ & $\mathrm{R}^{2} \%$ \\
\hline \multicolumn{7}{|c|}{ Landrace $(n=119)$} \\
\hline 1 & Meat + bone of ham, $g$ & 0.85 & 72 & Meat + bone of ham, $\%$ & 0.81 & 66 \\
\hline 2 & $" \quad$ of shoulder, $\mathrm{g}$ & 0.54 & 83 & $" \quad$ of shoulder, $\%$ & 0.58 & 79 \\
\hline 3 & of fore back, $g$ & 0.58 & 88 & of fore back, $g$ & 0.32 & 85 \\
\hline 4 & of back, $\mathrm{g}$ & 0.59 & 96 & of back, \% & 0.49 & 94 \\
\hline 5 & of carrè, $\mathrm{g}$ & 0.59 & 98 & of carrè, \% & 0.53 & 96 \\
\hline 6 & Index & 0.78 & 98 & " of carrè, $\mathrm{g}$ & 0.43 & 98 \\
\hline 7 & Age, day & -0.05 & 100 & Feed consumption fu/kg & -0.14 & 98 \\
\hline 8 & Meat + bone of carrè, \% & 0.45 & 100 & & & \\
\hline
\end{tabular}

r $>0.19$ signif. at $5 \%$ level; r $>0.24$ signif. at $1 \%$ level; r $>0.31$ signif. at $0.1 \%$ level.

\begin{tabular}{|c|c|c|c|c|}
\hline \multicolumn{5}{|c|}{ Yorkshire $(n=77)$} \\
\hline 1 & Meat + bone & of ham, $\mathrm{g}$ & 0.82 & 67 \\
\hline 2 & n & of back, $\mathrm{g}$ & 0.81 & 86 \\
\hline 3 & " & of shoulder, $\mathrm{g}$ & 0.35 & 92 \\
\hline 4 & " & of fore back, $g$ & 0.57 & 98 \\
\hline 5 & " & of carrè, $\mathrm{g}$ & 0.61 & 100 \\
\hline 6 & Slaughter los & s, \% & -0.37 & 100 \\
\hline 7 & Index & & 0.78 & 100 \\
\hline
\end{tabular}

$\begin{array}{lrr}\text { Index } & 0.79 & 61 \\ \text { Meat + bone component g per day } & 0.54 & 100 \\ \text { Skin +fat of shoulder, \% } & 0.30 & 100 \\ \text { Slaughter loss, \% } & 0.07 & 100 \\ \text { Skin + fat ham, \% } & -0.47 & 100\end{array}$

r $>0.22$ signif. at $5 \%$ level; r $>0.29$ signif. at $1 \%$ level; r $>0.37$ signif. at $0.1 \%$ level. 
Meat + bone of the most valuable part. The estimation for the $\mathrm{L}$ a $\mathrm{nd} \mathrm{r}$ a c e of the meat + bone component of the most valuable part and its percentage included in five steps of the regression analysis, in the order listed: the meat + bone parts or their percentages of the ham, shoulder, fore back, back and carré (Table 5). The $\mathrm{R}^{2}$ percentages amounted to 98 and 96 . Attention is drawn to the introduction of the shoulder and the fore back after the ham. The information provided by the elements of the forecarcass concerning the meatiness of the most valuable part of the carcass was greater than that provided by the back, but there was no difference between the correlations of these three elements to the meat+bone component of the most valuable part. Mention should also be made of the very significant correlation of the index with the meat +bone component of the most valuable part $(\mathrm{r}=0.79 * * *)$ and its percentage $\left(\mathrm{r}=0.77^{* * *}\right)$.

The respective estimation for the $\mathrm{Y}$ o $\mathrm{rks}$ h i r e breed of the meat + bone component of the most valuable part and its percentage is shown in Table 5. The estimation of the meat+bone component included in five steps the meat+bone parts of the ham, back, shoulder, fore back and carré, in the order listed. After this, the $\mathrm{R}^{2}$ percentage was 100 . However, in the model measuring the percentage of the meat + bone component of the most valuable part there was included first the meatiness index $\left(R^{2} \%=61\right)$ and at the second step the growth of the meat+bone component per day $\left(R^{2} \%=100\right)$. The correlation $\left(\mathrm{r}=0.78^{* * *}\right)$ between the index and the meat + bone percentage of the most valuable part was greater than the correlations $(r=0.67 * * *$ and $r=0.74 * * *)$ between the meat + bone of the ham or its percentage and the meat + bone percentage of the most valuable part of the carcass.

The very significant correlation of the index with the meat + bone component of the most valuable part of the carcass as well as with its percentage is explicable in terms of the structure of the index or the postulated objectives thereof. The purpose of the index was to measure the growth of the meat + bone component of the most valuable part of the carcass and its proportion in the carcass. On the other hand, the index is also very significantly correlated with the skin + fat component of the most valuable part of the carcass and its percentage in both the breeds (Landrace $\mathrm{r}=-42 * * *$ and $\mathrm{r}=-0.54 * * *$, Yorkshire $\mathrm{r}=-0.34 * *$ and $\mathrm{r}=-0.54 * * *)$. A "two-sided" index for direct selection for small skin + fat component as well as selection for meat + bone could evidently be applied to speed up the development of a low-in-fat pig even with the present animal materiial. This is suggested, e.g. by a) the relatively great variation coefficients of the skin + fat component and its percentage (11.4 and 10.0) compared with the respective coefficients for the meat + bone component and its percentage (5.9 and 5.2), and b) the sufficiently high heritability values obtained for the skin+fat component (UUsisalmi 1969 a).

Restriction of dissection analysis to ham and back. On the basis of the above analyses it is possible to examine the chances that exist for restricting dissection analysis to a smaller part of the carcass, e.g. to the ham and the back. It would then be possible without extra cost to dissect the carré too, although the information provided by this is slight in comparison with the information provided by the parts mentioned above.

The estimation for the skin + fat component of the most valuable part of the carcass or its percentage (Tables 1 and 4) generally included first the skin +fat of the back or its percentage and second the skin + fat of the ham or its percentage. The $\mathrm{R}^{2}$ percentage was thereafter $72-77$.

The estimation of the meat +bone component of the most valuable part of the carcass or its percentage (Table 5) included first the meat+bone of the ham or its percentage $\left(\mathrm{R}^{2} \%=66-72\right)$. It is found on the basis of the correlation coefficients that the meat + bone of the ham is a better measurement than any other individual result of conventional carcass evaluation or of dissection when the meat + bone component of the most valuable part of the carcass is to be assessed. Earlier, Uusisalm (1971 b) obtained the results that $64-69$ per cet of the overall variance of the skin + fat component of the most valuable part of the carcass or its percentage could be explained by means of conventional carcass 
evaluation, as could 56-65 per cent of the variance of the meat + bone component or its percentage; $\mathrm{n}=153$. By comparing those results with the results now obtained, we find that the dissection of the back and the ham gives a picture of the fattiness of the carcass which is as good as or better than the picture obtained by total conventional carcass evaluation (see Fig. 1).

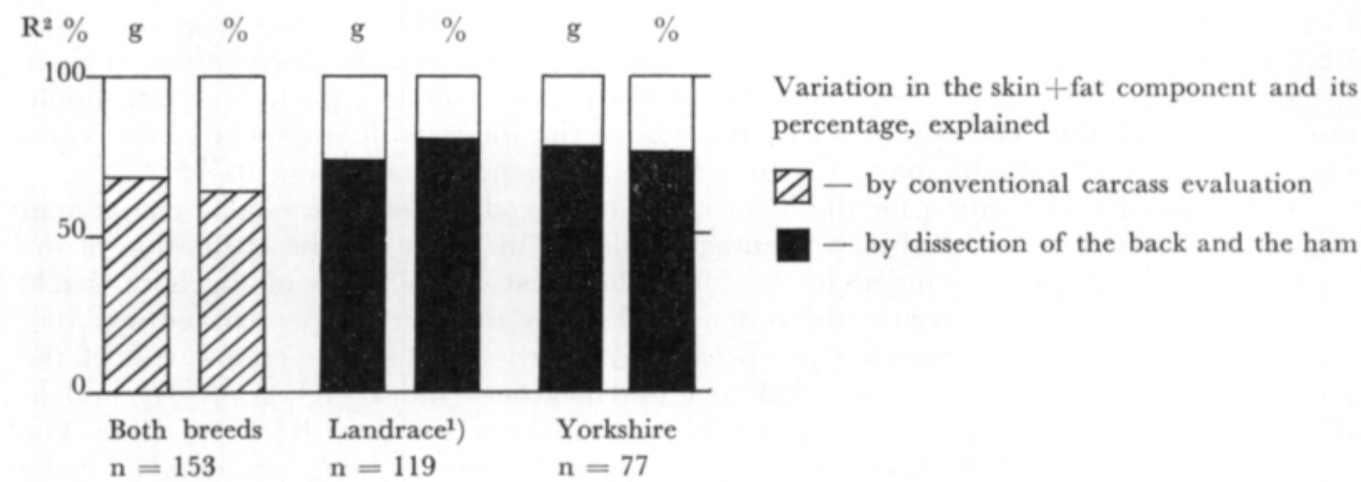

1) Thickness of back fat, and percentages of skin +fat components of the back and the ham.

Fig. 1. Variation in the skin + fat component of the most valuable part of the carcass and in its percentage, explained by results of conventional carcass evaluation and results of dissection of the back and the ham.

Table 6. The variation of the most valuable part of the carcass and some of its somponents, explained by the variations of the skin + fat parts of the back and the ham.

\begin{tabular}{|c|c|c|c|c|c|c|c|c|}
\hline \multirow[b]{2}{*}{$\mathbf{y}$} & \multicolumn{4}{|c|}{ Landrace $(n=119)$} & \multicolumn{4}{|c|}{ Yorkshire $(n=77)$} \\
\hline & $\mathbf{x}$ & $\mathbf{r}$ & $\mathbf{R}$ & $\mathbf{R}^{2} \%$ & $\mathbf{x}$ & $\mathbf{r}$ & $\mathrm{R}$ & $\mathbf{R}^{2} \%$ \\
\hline \multirow{2}{*}{ Skin + fat component, $g$} & 1) $\left\{x^{2}\right.$ & 0.74 & 0.74 & 55 & 1) $\int x^{2}$ & 0.81 & 0.81 & 66 \\
\hline & $\int x^{2}$ & 0.70 & 0.85 & 71 & $\left\{x^{2}\right.$ & 0.72 & 0.88 & 77 \\
\hline \multirow{2}{*}{ Meat + bone component, $\mathrm{g}$} & & -0.16 & & 3 & & -0.11 & & 0 \\
\hline & & -0.16 & 0.15 & 3 & & -0.07 & - & 0 \\
\hline \multirow[t]{2}{*}{ The most valuable part of carcass, $g$} & & 0.35 & & 12 & & 0.28 & & 8 \\
\hline & & 0.32 & 0.38 & 14 & & 0.28 & 0.28 & 8 \\
\hline \multirow[t]{2}{*}{ Skin +fat component, $\%$ of carcass } & & 0.70 & & 49 & & 0.78 & & 61 \\
\hline & & 0.64 & 0.80 & 64 & & 0.62 & 0.62 & 67 \\
\hline \multirow[t]{2}{*}{ The half carcass, $\mathrm{g}$} & & 0.35 & & 12 & & 0.24 & & 6 \\
\hline & & 0.37 & 0.41 & 17 & & 0.38 & 0.35 & 12 \\
\hline \multirow[t]{2}{*}{ Skin + fat of shoulder + fore back, $g$} & & 0.28 & & 8 & & 0.39 & & 14 \\
\hline & & 0.41 & 0.41 & 17 & & 0.37 & 0.41 & 17 \\
\hline \multirow[t]{2}{*}{ Skin + fat of back parts, $g$} & & 0.88 & & 76 & & 0.90 & & 81 \\
\hline & & 0.49 & 0.88 & 77 & & 0.51 & 0.90 & 81 \\
\hline \multirow[t]{2}{*}{ Skin + fat of back parts, $\%$ of carcass } & & 0.84 & & 71 & & 0.86 & & 74 \\
\hline & & 0.41 & 0.84 & 71 & & 0.39 & 0.86 & 74 \\
\hline
\end{tabular}

1) $\left\{\begin{array}{l}x^{2}=\text { Skin }+ \text { fat of back. } \\ x^{2}=\text { Skin +fat of ham. }\end{array}\right.$ 
Information obtained on the shoulder + fore back and the whole back by dissection of the ham and the back. In both breeds only 17 per cent of the variance in the skin + fat of the shoulder+fore back was explicable in terms of the variances in the skin+ fat parts of the ham and the back. In the Yorkshire breed it was not possible to assess even satisfactorily the meat + bone of the shoulder and fore back by means of the meat + bone of the back $\left(\mathrm{R}^{2} \%=34\right)$. But in the Landrace a good picture of the variance in the meat + bone of the shoulder and fore back was obtained from the meat + bone parts of the ham and the shoulder $\left(\mathrm{R}^{2} \%=62\right)$. It can be concluded from the results that restriction of dissection to the ham and the back will weaken the assessment of the carcass quality of the forepart of the carcass (Tables 6 and 7).

Table 7. The variation of the most valuable part of the carcass and some of its components, explained by the variations of the meat + bone parts of the ham and $\left\{\begin{array}{l}\text { the shoulder (Landrace) } \\ \text { the back (Yorkshire). }\end{array}\right.$

\begin{tabular}{|c|c|c|c|c|c|c|c|c|}
\hline \multirow[b]{2}{*}{ y } & \multicolumn{4}{|c|}{ Landrace $(\mathrm{n}=119)$} & \multicolumn{4}{|c|}{ Yorkshire $(\mathrm{n}=77)$} \\
\hline & $\mathbf{x}$ & $\mathbf{r}$ & $\mathbf{R}$ & $\mathbf{R}^{2} \%$ & $\mathbf{x}$ & $\mathbf{r}$ & $\mathbf{R}$ & $\mathbf{R}^{2} \%$ \\
\hline \multirow[t]{2}{*}{ Skin + fat component, $g$} & 1) $\int x_{1}$ & -0.31 & 0.31 & 10 & $\left.{ }^{2}\right) \int \mathrm{x}_{1}$ & -0.18 & 0.18 & 3 \\
\hline & $\left\{x_{2}\right.$ & -0.26 & 0.33 & 11 & $\left\{x_{2}\right.$ & 0.06 & 0.21 & 4 \\
\hline \multirow{2}{*}{ Meat + bone component, $\mathrm{g}$} & & 0.85 & & 72 & & 0.82 & & 67 \\
\hline & & 0.54 & 0.91 & 83 & & 0.81 & 0.93 & 86 \\
\hline \multirow[t]{2}{*}{ The most valuable part of carcass, $g$} & & 0.58 & & 34 & & 0.65 & & 42 \\
\hline & & 0.33 & 0.59 & 35 & & 0.76 & 0.81 & 66 \\
\hline \multirow[t]{2}{*}{ Meat + bone component, $\%$ of carcass } & & 0.62 & & 38 & & 0.66 & & 44 \\
\hline & & 0.52 & 0.71 & 50 & & 0.48 & 0.67 & 45 \\
\hline \multirow[t]{2}{*}{ The half carcass, $\mathrm{g}$} & & 0.43 & & 18 & & 0.52 & & 27 \\
\hline & & 0.11 & 0.42 & 18 & & 0.71 & 0.72 & 52 \\
\hline \multirow[t]{2}{*}{ Meat + bone of shoulder + fore back, $g$} & & 0.46 & & 21 & & 0.47 & & 22 \\
\hline & & 0.75 & 0.79 & 62 & & 0.56 & 0.58 & 34 \\
\hline \multirow[t]{2}{*}{ Meat + bone of back parts, $g$} & & 0.61 & & 37 & & 0.55 & & 30 \\
\hline & & 0.20 & 0.61 & 37 & & 0.87 & 0.87 & 76 \\
\hline
\end{tabular}

2) $\left\{\begin{array}{l}\mathrm{x}_{1}=\text { Meat }+ \text { bone of ham } \\ \mathrm{x}_{2}=\text { Meat }+ \text { bone of back }\end{array}\right.$

The fattiness of the whole back (= fore back + back + carré) could be well assessed in both breeds from the skin + fat of the back $\left(\mathrm{R}^{2} \% 71-81\right)$, however, dissection on the ham performed in addition to dissection on the back did not improve the result in this respect. In the Yorkshire breed 76 per cent of the variance in the meat+bone of the back parts could be explained from the variance in the meat+bone parts of the back and the ham. In the Landrace it was found that the variance in the meat+bone components of the ham and the shoulder explained 37 per cent of the variance in the meat + bone of all the back parts.

Simplified dissection and conventional carcass evalua$\mathrm{t} \mathrm{i}$ o $\mathrm{n}$. If dissection of the most valuable part of the carcass is reduced merely to dissec- 
tion of the ham and the back, the emphasis in selection will be transferred to these parts of the carcass. The ham and the back admittedly amount to c. 35 per cent of the half carcass, and in the retail trade they are among the parts which are most in demand and most valued. Thus their dissection into skin + fat and meat+bone components also involves a considerable expenditure on testing, in the form of reduction in the value of the half carcass.

As the picture of the quality of the entire carcass becomes somewhat biased in some respects owing to the restricted dissection analysis, it would be worth while to maintan, or at least occasionally to employ, conventional carcass evaluation for back fat or s.o.l., area of $\mathrm{m}$. long. dorsi and length of carcass. These characteristics would also be control measurements of the development. Increasing attention should also be paid to the measurements of the development. Increasing attention should also be paid to the measurement of meat quality (e.g. colour of meat). Measurement notes should likewise be made of daily gain and feed consumption.

\section{REFERENCES}

BLEND, H. M. 1966 a. Objektive Methoden zur Bestimmung des Schlachtkörperwertes beim Schwein als Hilfsmittel für die züchterische Selektion. Zũcht. kunde 38: 234-246.

BLEND, H. M. 1966 b. Die Muskelflächen des Schinkens und ihre Beziehungen zum Fleisch- und Fettanteil im Schinken und Schlachtkörper sowie dem Schinkengewicht. Zũcht. kunde 38: 362-377.

Böckenhoff, E., Fewson, D. \& Bischoff, T. 1967. Die wirtschaftliche Bedeutung verschiedener Leistungsmerkmale beim Schwein und ihre Auswirkung auf die Zuchtarbeit. 1. Mitteilung. Zūcht. kunde 39: $270-282$.

Clauusen, HJ., Thomsen, R. N. \& Pedersen, O. K. 1970. Sammenlignende forsog med svin fra statsanerkendte aviscentre 1967-68 og 1968 - 69. 379. beretning fra forsegslaboratoriet: $1-76$, Cobenhavn 1970.

HARVEY, W. R. 1966. Least-squares analysis of data with unequal subclass numbers. ARS 20-28. July 1960. Reprinted with corrections April 1966. Agric. Res. Service U.S. Dept. of Agric.

Lohse, B., Flock, D. \& Schröder, J. 1969. Untersuchung über die Schlachtkörperzusammensetzung von Schweinen in Abhängigkeit vom Endgewicht (90-150 kg). Zũcht. kunde 41: 24-35.

Partanen, J. 1969. Mastleistungsprüfungen in Finnland. Europäische Vereinigung für Tierzucht, Schweinekomission, Helsinki 24. Juni 1969.

Pedersen, O. K. 1968. Sikojen teuraslaatu (Carcass quality of pigs) In Finnish. Sika 5: 5-18.

SCC 1968. Kovarianssianalyysi (Covariance analysis). Valikoiva regressioanalyysi (Multiple stepwise regression analysis). State Computing Center. Dep. of Planning, $\times 40,1578$.

SснӧN, I. 1970. Möglichkeiten und Grenzen der Einflussnahme des Verbrauchers auf Entwicklungstendenzen im Fleischangebot. Zũcht. kunde 42: 219-232.

Sych, E. \& Horst, P. 1969. Untersuchungen über die jahreszeitliche Variation der Teilstückpreise und die Möglichkeit der Abschätzung des Geld wertes der Schlachthälften beim Schwein. Zũcht. kunde 41: $437-456$.

Uusisalmi, U. 1969 a. Vorläufige Ergebnisse über das Messen der Schlachteigenschaften beim Schwein. J. Sci. agric. Soc. Finland 41: 50-59.

Uustsalmi, U. 1969 b. Carcass analysis as aid in pig breeding. Acta Agr. Scand. 19: 214-220.

Uusisalmi, U. 1971 a. Inheritance in ham and its components in the Finnish Landrace and Yorkshire breeds. Acta Agr. Scand. 21: 73-83.

Uusisalmi, U. 1971 b. The conventional carcass evaluation and the carcass dissection analysis of pigs. J. Sci. Agr. Soc. Finland 43: 40-52.

Weniger, J. H., Kallweit, E., Steinhauf, D. \& Glodek, P. 1967. Einfluss des Wachstums auf Teilstückgewichte und Schlachtkörpermasse beim Schwein. Zũcht. kunde 39: 188-199. 


\title{
SELOSTUS
}

\section{RAJOITETTU LEIKKELYANALYYSI MAATIAIS- JA YORKSHIRERODUILLA}

\author{
Unto Uusisalmi \\ Helsingin yliopisto \\ Kotieläinten jalostustieteen laitos
}

Tutkittiin leikkelyanalyysin ja sen ohella perinteellisen teurasarvostelun antamaa informaatiota teuraslaadusta sekä maatiais- että yorkshireroduilla.

Pohjanmaan sikatalouskoeaseman kantakoesiat $(\mathrm{n}=196)$ teurastettiin noin $90 \mathrm{~kg}: \mathrm{n}$ elopainossa. Perinteellisen teurasarvostelun jälkeen ruhon puolisko paloiteltiin ja puoliskon arvokkaimmasta osasta (kinkku + carré + kyljysselkä + etuselkä + lapa + munuaisrasvat) erotettiin nahka + rasva liha +luusta. Laskettiin kullekin sialle mlihakkuusindeksi» $\left(=\frac{A}{B} \times \frac{A}{C} \times 10\right)$, jossa $A=$ ruhon puoliskon arvokkaimman osan liha+luun paino, $\mathrm{B}=$ ikä päiviä ja $\mathrm{C}=$ ruhon puoliskon paino.

Pienimmän neliösumman menetelmän (HARVEY 1966) avulla todettiin ruhon arvokkaimmasta osasta ja sen nahka + rasva- ja liha +luu-komponenteista seuraavaa: Teuraspainoerot vaikuttivat erittäin merkitsevästi ruhon arvokkaimman osan ja sen komponenttien painon muunteluun. Niiden suhteellisissa osuuksissa teuraspainon vaikutusta ei havaittu. Ikäerojen aiheuttamalla muuntelulla ei ollut merkitystä. Naaraseläimillä oli erittäin merkitsevästi keveämpi arvokkaimman osan nahka + rasva- komponentti ja raskaampi liha+luu-komponentti kuin leikoilla.

Valikoivan regressioanalyysin avulla analysoitiin teuraslaadun mittamista erikseen molemmilla roduilla. Näin saatiin arvioita ruhon arvokkaimmalle osalle, sen komponenteille ja näiden \%-osuuksille. Varsinkin nahka + rasva-komponentin arvioiden todettiin vastaavan hyvin toisiaan molemmilla roduilla. Rajoitetun leikkelyanalyysin ohella todettiin seuraavat perinteellisen teurasarvostelun tulokset merkitykseilisiksi teuraslaadun arvostelussa: selkäsilava tai kylkisilava, selkälihaksen ala, lihan väri, kasvu- ja rehunkäyttökyky.

Kinkun ja kyljysselän leikkelyn avulla saatiin hyvä kuva $\left(R^{2} \% \geqq 72\right)$ ruhon arvokkaimman osan teuraslaadusta, mutta heikohko kuva lapa +etuselän teuraslaadusta.

Indeksi korreloitui seuraavasti arvokkaimman osan nahka+rasvaan ja sen $\%$-osuuteen, $\mathrm{r}=$ $-0.34 * *-0.55^{* * *}$, liha+luuhun ja sen $\%$-osuuteen, $\mathrm{r}=0.77^{* * *}-0.78^{* * *}$. 